\title{
Numerical modeling of Slug flows in multiphase pipeline system of lion offshore oil fields
}

- Hoa Do Xuan ${ }^{1}$

- Lan Mai Cao ${ }^{2}$

${ }^{1}$ Cuu Long Joint Operating Company

${ }^{2}$ Faculty of Geology \& Petroleum Engineering, Department of Drilling \& Production, Ho Chi Minh city University of Technology, VNU-HCMC

(Manuscript Received on July 05 ${ }^{\text {th }}$, 2015; Manuscript Revised on September 30 ${ }^{\text {th }}$, 2015)

\begin{abstract}
Oil and gas transportation by the pipelines among different production wells from one or more reservoirs is one primary part of an oil field development plan. When multiple pipelines transporting oil and gas from different fields are collected on the same Central Processing Platform (CPP) or Floating Production Storage Offloading (FPSO), however, the fluid behavior in multiphase flow pipelines become more complicated and often cause slugging problems that badly impact on downstream facility performance. It is, therefore, necessary to
\end{abstract}

investigate the slug flow to control and/or improve flow stability in the pipeline systems. In this paper, the workflow for building and calibrating a multiphase flow model are described. The numerical model is then applied for the pipeline system of Lion oilfields in Cuu Long Basin, Southern Vietnam. Sensitivity analysis have been performed to investigate the influences of various factors on the slug flow in the pipeline system. The results from this work would be useful for tracking and controlling the slugging effect on the separator performance.

Key words: Flow assurance, slug flow, multi-phase flow.

\section{INTRODUCTION}

The tie-in development planning is one of the most effective solutions to reduce the cost needed to construct the treatment and storage facilities and/or transportation of petroleum products from small or marginal reservoirs in harsh offshore environment. With this solution, the oil \& gas gathered to the wellhead systems from different reservoirs will be transported through subsea pipeline systems to a processing and treatment facilities system at Central Processing Platform (CPP) or Floating Production Storage and Offloading (FPSO). However, there always existsthe problems associated withflow in the pipeline include transient slugging, wax deposition, and hydrates. The task for building the reliable model to predict the impact of these phenomenon on 
operating offshore production systems is, therefore, essential.

N.E. Burke et all (1993) presented anapproach for history matching the startup conditions measured for a burried offshore North Sea oil flowlineand evaluated effects of PVT fluid, thermal properties in match. The wellhead and platform arrival temperature, pressure, and flow rates were predicted as the production rate varied during startup. These type of datastudy is useful for designing treatment and prevention programs for hydrate and wax deposition in offhore flowlines.In the paper (Y. Tang, T. Danielson, 2006), based on the combination of the slug tracking model with separator gas/liquid PID controllers, the model with a remakably good match of pressure variations, slugging frequency and liquid level was achieved and used for solving the slugging problems at Alpine facility, on the Alaskan North Slope. S.C. Omowunmi et all (2013) also described a methodology for characterising slugs based on OGLA slug tracking module and applied this in studies related to dynamic slug control in the Egina deepwater project, West African.

In this study, based on the theory of multiphase flow together with the dynamic multiphase flow simulator, the thermo-hydraulic model for subsea pipeline tie-in system amongLionoil fields at Block 15.1 in Cuu Long Basin, offshore Southern Vietnam is built. Also, the history matching exercise is conductedby tunning model to match the slugging behavior as observerd in the field.

\section{DESCRIPTION OF THE MODEL}

\subsection{The Multiphase Flow Model Theory}

The framework for this study is a twophase flow model developed by (Kjell H.Bendiksen, Dag Maines, Randl Moe, and Sven Nuland, 1991).The model is based on fundamental physics of multiphase flow systems and has the capacity of predicting hydrodynamic slug formation and propagation in two-phase flow by solving five coupled mass-conservation equations, three momentum-conservation equations, and one energy balance equation for a three-phase system.

Mass-Conservation Equations. For gas phase,

$$
\begin{aligned}
\frac{\partial}{\partial t}\left(V_{g} \rho_{g}\right)= & -\frac{1}{A} \frac{\partial}{\partial x}\left(A V_{g} \rho_{g} v_{g}\right) \\
& +\psi_{g}+G_{g}
\end{aligned}
$$

For liquid phase at pipe wall,

$$
\begin{aligned}
& \frac{\partial}{\partial t}\left(V_{L} \rho_{L}\right)=-\frac{1}{A} \frac{\partial}{\partial x}\left(A V_{L} \rho_{L} v_{L}\right) \\
& -\psi_{g} \frac{V_{L}}{V_{L}+\alpha_{D}}-\psi_{e}+\psi_{d}+G_{L}
\end{aligned}
$$

For liquid droplets,

$$
\begin{aligned}
& \frac{\partial}{\partial t}\left(V_{D} \rho_{L}\right)=-\frac{1}{A} \frac{\partial}{\partial x}\left(A V_{D} \rho_{D} v_{D}\right) \\
& -\psi g \frac{V_{D}}{V_{L}+V_{D}}-\psi_{e}+\psi_{d}+G_{D}
\end{aligned}
$$

For phase transfer between phases,

$$
\begin{aligned}
& {\left[\frac{V_{g}}{\rho_{g}}\left(\frac{\partial \rho_{g}}{\partial p}\right)_{T, R_{s}}+\frac{1-V_{g}}{\rho_{L}}\left(\frac{\partial \rho_{L}}{\partial p}\right)_{T, R_{s}}\right] \frac{\partial p}{\partial t}=} \\
& -\frac{1}{A \rho_{g}} \frac{\partial\left(A V_{g} \rho_{g} v_{g}\right)}{\partial z}-\frac{1}{A \rho_{L}} \frac{\partial\left(A V_{L} \rho_{L} v_{L}\right)}{\partial z} \\
& -\frac{1}{A \rho_{L}} \frac{\partial\left(A V_{L} \rho_{L} v_{L}\right)}{\partial z}+\psi_{g}\left(\frac{1}{\rho_{g}}-\frac{1}{\rho_{L}}\right) \\
& +G_{g} \frac{1}{\rho_{g}}+G_{L} \frac{1}{\rho_{L}}+G_{D} \frac{1}{\rho_{L}}
\end{aligned}
$$

For interfacial mass-transfer rate,

$$
\begin{aligned}
& \psi_{g}= {\left[\begin{array}{l}
\left(\frac{\partial R_{s}}{\partial p}\right)_{T} \frac{\partial p}{\partial t}+\left(\frac{\partial R_{s}}{\partial p}\right)_{T} \frac{\partial p}{\partial z} \frac{\partial z}{\partial t} \\
+\left(\frac{\partial R_{s}}{\partial p}\right)_{p} \frac{\partial T}{\partial t}+\left(\frac{\partial R_{s}}{\partial T}\right)_{p} \frac{\partial T}{\partial z} \frac{\partial z}{\partial t}
\end{array}\right] } \\
& \times\left(m_{g}+m_{L}+m_{D}\right)
\end{aligned}
$$


Where $R_{s}=\frac{m_{g}}{m_{g}+m_{L}+m_{D}}$

Momentum-Conservation Equations.For gas phase,

$$
\begin{aligned}
& \frac{\partial}{\partial t}\left(V_{g} \rho_{g} v_{g}\right)=-V_{g}\left(\frac{\partial p}{\partial x}\right)-\frac{1}{A} \frac{\partial}{\partial x}\left(A V_{v g} \rho_{g} v_{g}^{2}\right) \\
& -\lambda_{g} \frac{1}{2} \rho_{g}\left|v_{g}\right| v_{g} \frac{S_{g}}{4 A}-\lambda_{i} \frac{1}{2} \rho_{g}\left|v_{r}\right| v_{r} \frac{S_{i}}{4 A} \\
& +V_{g} \rho_{g} g \cos \alpha+\psi_{g} v_{a}-F_{D}
\end{aligned}
$$

For liquid phase at pipe wall,

$$
\begin{aligned}
& \frac{\partial}{\partial t}\left(V_{L} \rho_{L} v_{L}\right)=-V_{L}\left(\frac{\partial p}{\partial x}\right)-\frac{1}{A} \frac{\partial}{\partial x}\left(A V_{L} \rho_{L} v_{L}^{2}\right) \\
& -\lambda_{L} \frac{1}{2} \rho_{L}\left|v_{L}\right| v_{L} \frac{S_{L}}{4 A}+\lambda_{i} \frac{1}{2} \rho_{g}\left|v_{r}\right| v_{r} \frac{S_{i}}{4 A} \\
& +V_{L} \rho_{L} g \cos \alpha-\psi_{g} \frac{V_{L}}{V_{L}+V_{D}} v_{a}-\psi_{e} v_{i} \\
& +\psi_{d} v_{D}-V_{L} d\left(\rho_{L}-\rho_{g}\right) g \frac{\partial V_{L}}{\partial x} \sin \alpha
\end{aligned}
$$

For liquid droplets,

$$
\begin{aligned}
& \frac{\partial}{\partial t}\left(V_{D} \rho_{L} v_{D}\right)=-V_{D}\left(\frac{\partial p}{\partial x}\right) \\
& -\frac{1}{A} \frac{\partial}{\partial x}\left(A V_{D} \rho_{L} v_{D}^{2}\right) \\
& +V_{D} \rho_{L} g \cos \alpha-\psi_{G} \frac{V_{D}}{V_{L}+V_{D}} v_{a} \\
& +\psi_{e} v_{i}-\psi_{d} v_{D}+F_{D}
\end{aligned}
$$

Where $\mathrm{v}_{\mathrm{a}}=\mathrm{v}_{\mathrm{L}}$ for $\Psi_{g}>0$ (and evaporation from the liquid film), $v_{\mathrm{a}}=\mathrm{v}_{\mathrm{D}}$ for $\Psi_{g}>0$ (and evaporation from the liquid droplets), $\mathrm{v}_{\mathrm{a}}=\mathrm{v}_{\mathrm{g}}$ for $\Psi_{g}<0$ (condensation).

Mixture Energy Conservation Equation. An energy conservation equation for the mixture is derived as follows:

$$
\begin{gathered}
\frac{\partial}{\partial t}\left[\begin{array}{c}
m_{g}\left(E_{g}+\frac{1}{2} v_{g}^{2}+g h\right) \\
+m_{L}\left(E_{L}+\frac{1}{2} v_{L}^{2}+g h\right) \\
+m_{D}\left(E_{g}+\frac{1}{2} v_{g}^{2}+g h\right)
\end{array}\right] \\
=\frac{\partial}{\partial x}\left[\begin{array}{l}
m_{g} v_{g}\left(H_{g}+\frac{1}{2} v_{g}^{2}+g h\right) \\
+m_{L} v_{L}\left(H_{L}+\frac{1}{2} v_{L}^{2}+g h\right) \\
+m_{D} v_{D}\left(H_{D}+\frac{1}{2} v_{D}^{2}+g h\right)
\end{array}\right]+H_{S}+U
\end{gathered}
$$

Where $E$ is the internal energy per unit mass, $H$ is the enthalpy, $h$ is the elevation, $H_{s}$ is the enthalpy from mass source, and $Q$ is the heat transfer from the pipe walls.

\subsection{Modeling Of the Pipeline Connection System at Block 15.1}

\subsubsection{A Brief Subsea Pipeline Connection System Description}

A typical subsea pipeline connection system at Block 15.1 scheme, as shown in Figure 1, is used in this study. It consist of eight Wellhead Platform, STN-N, STN-S, SDNE, SDSW, SVNE, SVSW, STT, STV which were tied-in through subsea pipelines system and transfer to a Central Processing Platform.

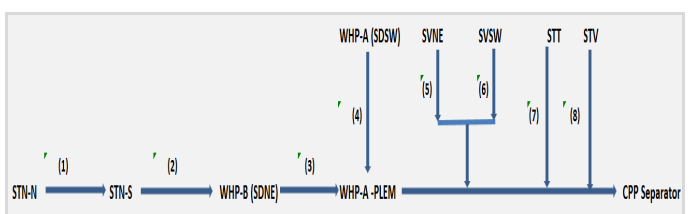

Figure 1. A generic subsea pipeline connection system at Block 15.1

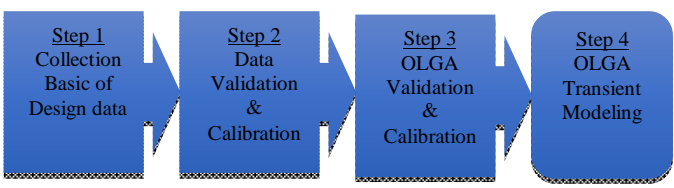

Figure 2. The major steps for building the thermohydraulic model. 


\subsubsection{Work Flow for Building Thermo- Hydraulic Model}

The typical work flow in the model building began with the understanding of fluids properties. The basis of design document is developed to identify and summarize the design inputs of the facilities. The steps modeling of the subsea pipeline connection system at Block 15.1 using OLGAis performed, as show in Figure 2.

\section{Step 1 - Collection Basic of design data:}

Collecting the following data and building the model in OLGA as shown in Figure 3.

- Bathymetry data for production pipeline from WHPs to CPP.

- Fluid Properties (e.g. Fluid composition, viscosity, GOR, and water cut). The fluid properties must be defined by PVTsim before input to OLGA.

- Material Properties for the pipeline (e.g. Thermal conductivity, material density, thermal capacity).

- Coating thickness for each pipeline section.

- Environment data (e.g. Seawater temperature, air temperature, seawater and air velocity).

- Process equipment (e.g. valves, separator, and controllers).

Step 2 - Data Validation \&Calibration:

Some data from basic of design has changed during production operation, for instance, fluid composition, GOR, and water cut... Therefore, the data need to be corrected or tuned to current condition.

\section{Step 3 - OLGA Validation \& Calibration:}

This step is done through quality checking on operational conditions such as, the boundary, source, and initial conditions. The boundary conditions specify the actual boundary conditions and any mass sources or sinks along the pipe. The source is a location where the fluid enters the system. The initial conditions group specifies the initial values for pressure, gas volume fraction, total mass flow, and fluid temperature for each section of the pipeline, as shown in Table 1. In this model, a fixed pressure of 296 psig and 140 psig were used as the boundary pressures for the STN and CPP separator gas outlet line, respectively.

\section{Step 4 - OLGA Transient Modeling:}

In this case study,the Central Processing Platform of Lion fields has recently experienced slugging problems severe which enough to trip the high-high inlet separator level, as shown in Figure 4, cause frequent plant shutdowns and loss production of $80 \mathrm{kbbl} / \mathrm{d}$.

To ensure the model has ability capture the mechanisms of slug growth, decay, and merging of slugs, also, reduce the simulation time, the OLGA Slug Tracking model must be appliedsuitably for each flowline.

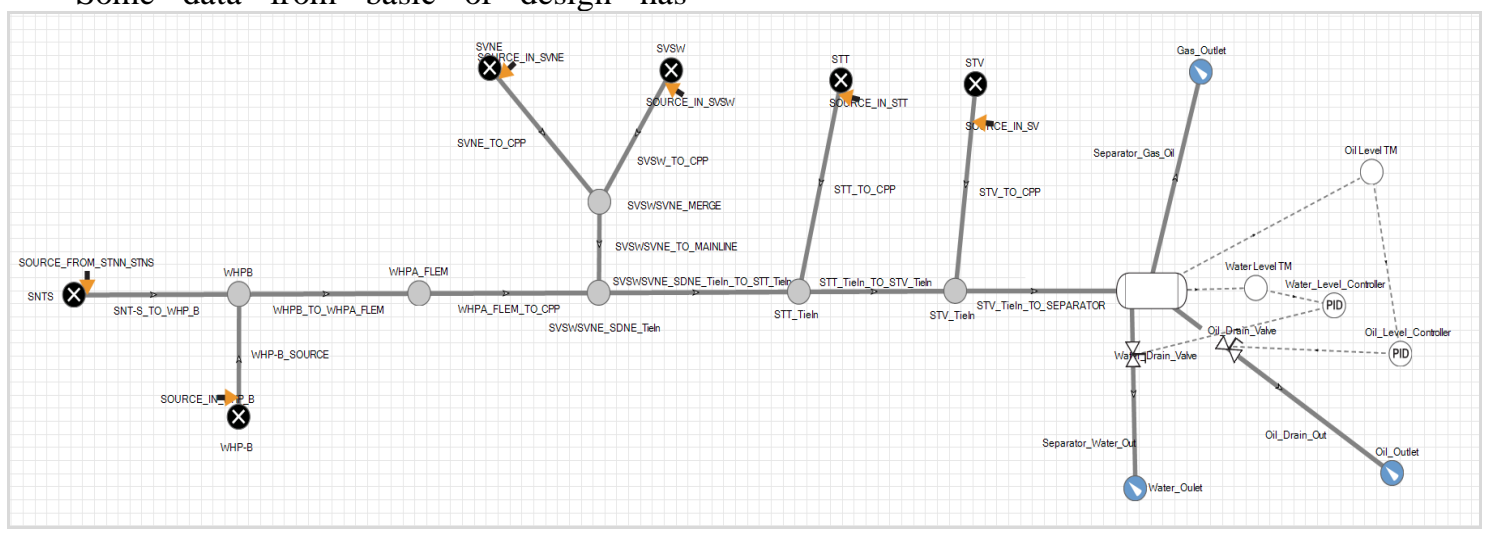

Figure 3. The pipeline connection system model at Block 15.1 

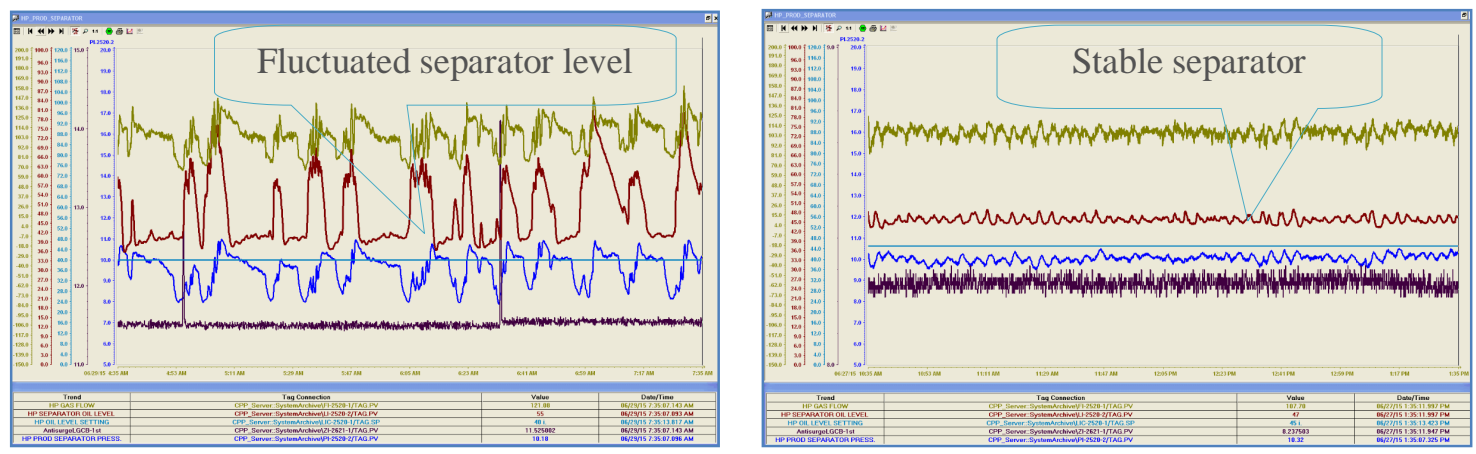

Figure 4. Level of CPP Separator before (left) and after (right) shutdown WHP-STN

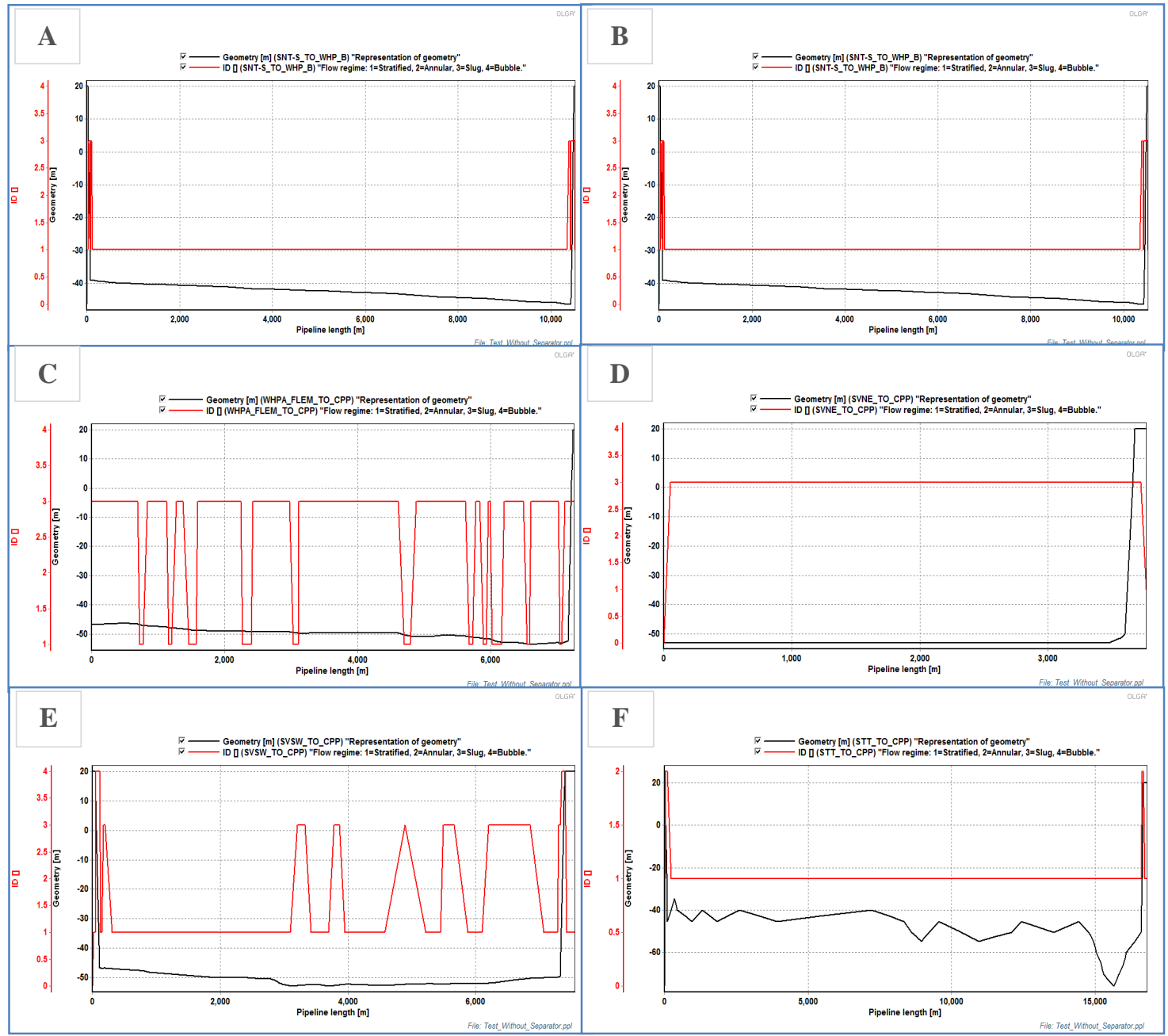

Figure 5. Flow regime indicator (ID) for each flowline 
Table 1. Input Operational Conditions for Model

\begin{tabular}{|c|c|c|c|c|c|c|c|c|}
\hline \multirow{2}{*}{ Parameter } & \multicolumn{7}{|c|}{ Source \& Initial Condition } & \multirow{2}{*}{ Unit } \\
\hline & STN & WHP-B & SVNE & SVSW & STT & SV & CPP & \\
\hline $\mathrm{Q}_{\text {gas }}$ & 3.94 & 39.471 & 2.55 & 1.88 & 59.87 & 11.27 & - & MMSCFD \\
\hline $\mathrm{Q}_{\text {oil }}$ & 43,129 & 6,311 & 1,000 & 4,042 & 7,629 & 3,041 & - & BOPD \\
\hline $\mathrm{Q}_{\text {water }}$ & 900 & 20,717 & 2,000 & 53.49 & 162 & 31,516 & - & BWPD \\
\hline QLiquid $_{\text {L }}$ & 44,029 & 27,028 & 3,000 & 4,096 & 7,791 & 34,557 & - & BOPD \\
\hline $\mathrm{M}_{\text {total }}$ & 63.354 & 59.577 & 6.121 & 7.265 & 59.448 & 65.015 & - & $\mathrm{kg} / \mathrm{s}$ \\
\hline GOR & 16.250 & 1,108 & 454 & 83 & 1,398 & 660 & - & $\mathrm{Sm}^{3} / \mathrm{m}^{3}$ \\
\hline $\mathrm{T}$ & 110 & 75 & 85 & 80 & 105 & 150 & 66.00 & ${ }^{\circ} \mathrm{C}$ \\
\hline $\mathrm{P}$ & 296 & 230 & 205 & 185 & 515 & - & 140 & psig \\
\hline $\begin{array}{l}\text { Water } \\
\text { Fraction }\end{array}$ & 0.0266 & 0.7759 & 0.686 & 0.0151 & 0.03 & 0.9379 & - & - \\
\hline
\end{tabular}

OLGA slug tracking model uses the delay constant to determine the required time delay between generations of slugs in a particular section. Time delay $\Delta \mathrm{t}$ between new slugs is determined by:

$$
\Delta t=D C \frac{d}{V_{L}},
$$

Note that the delay constant should be defined based on the actual liquid velocity instead of the superficial fluid velocity. The time delay is inversely related to the slug frequency (FS) and the above equation be rearranged as follows:

$$
D C=\frac{V_{L}}{d . \mathrm{F}_{s}}
$$

In the OLGA simulation, a default value 150 is used for the delay constant. Shea et al. suggested use the following empirical correlation to check the OLGA predicted frequency to make sure it falls in the reasonable range:

$$
F_{s}=\frac{0.47 V_{S L}}{d^{1.2} \cdot L^{0.55}}
$$

Where, $d=$ pipeline diameter, $\mathrm{m} ; \mathrm{V}_{\mathrm{L}}=$ real liquid velocity, $\mathrm{m} / \mathrm{s} ; \Delta \mathrm{t}=$ time delay, sec; $\mathrm{DC}=$ delay constant; $F_{s}=$ slug frequency, slug/sec. Before using Slug Tracking model, OLGA dynamic simulation is run until a steady-state solution is reached and the flow regime indicator, ID, is examined. If $\mathrm{ID}=3$, indicating slug flow regime, the slug tracking option would be run, if $\mathrm{ID}=1$, indicating stratified flow regime, slug tracking option is not required.Through the results, as shown in Figure 5, the OLGA Slug Tracking model should be usedfor the following flowline such as, WHP_B_TO_WHPA_FLEM (Figure 5B), WHPA_FLEM_TO_CPP (Figure 5C), SVNE_CPP (Figure 5D), and SVSW_CPP (Figure 5E).With the slug tracking option turned on, the simulation is run for additional time ( 5 hours simulation in this case) and a default DC value of 150 is used for delay constant to check the confidence level model and predict results close to field data. 


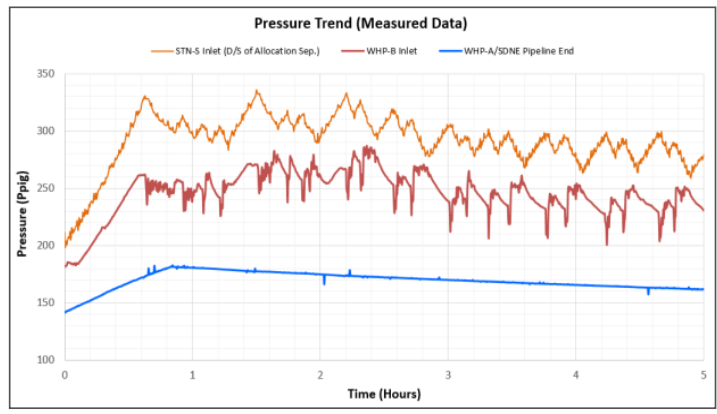

Figure 6. Pressure trend at STN-S/WHP-B/ CPP

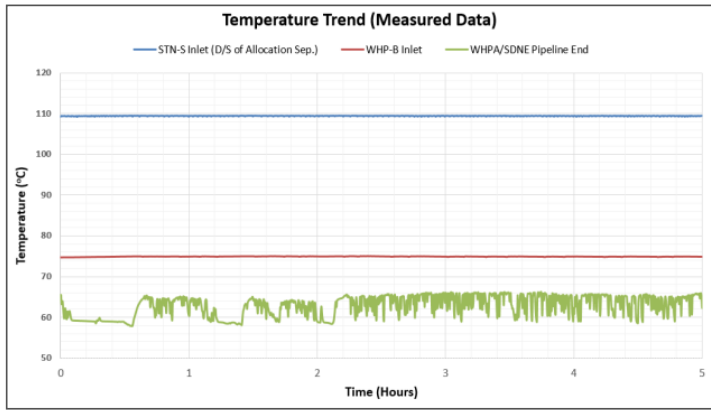

Figure 7. Temperature trend at STN-S/WHP-B/ CPP

The temperature and pressure trend results, as shown in Figure 6 and Figure 7, is different with the measured data, as shown in Figure 10 and Figure 12, respectively. Therefore, the history matching step need to be performed to confirm the validity and accuracy of the OLGA model.

\section{HISTORY MATCHING}

The purpose of the history matching is to validate the models as closely imitating the condition in the field. This work is performed by tuning the models to match field pressures and temperature in the system. An iterative simulation workflow for history matching is shown in Figure 8, with step 1 to step 4 is carried out similarly as presented in section 2.2.2. The step Field Matching will be described in detail below.

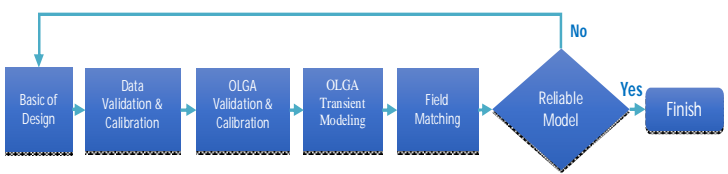

Figure 8. Work flow modeling and history matching model

The parameters which is considered for the history matching include production rates (shown in Table 1, the actual environmental data (shown in Table 2), the pressure and temperature at boundary (shown in Table 3), with the boldedvalue is fixed input data, and italicvalue is used for sensitivity studies to obtain a good match.

Table 2.Ambient Temperature for History Matching

\begin{tabular}{|c|c|}
\hline Parameter & Temperature $\left({ }^{\circ} \mathbf{C}\right)$ \\
\hline Air Temperature & 27.3 \\
\hline Water Temperature & 27 \\
\hline
\end{tabular}

Table 3. Pressure \& Temperature at Boundary for History Matching

\begin{tabular}{|c|c|c|}
\hline Platform/Location & Pressure (psig) & Temperature $\left({ }^{\mathbf{}} \mathbf{C}\right)$ \\
\hline STN-S & $250-270$ & $\mathbf{1 1 0}$ (Fixed value) \\
\hline WHP-B Inlet & $215-245$ & $\mathbf{7 5}$ (Fixed value) \\
\hline Separator (at CPP) & $\mathbf{1 4 0}$ (Fixed value) & $\mathbf{6 6}$ (Fixed value) \\
\hline
\end{tabular}

The delay constant DC in the OLGA slug tracking module is adjusted in order to match the pressure fluctuation as observed in the field. Although the OLGA default delay constant of 150 usually gives reasonable prediction for a single system, it was found that this value gives a too much high slugging frequency for measured system in this study. A delay constant of 2000 to match the measured field with slug frequency (Fs) of 4 slugs/hr (shown in Figure 4). 
Table 4 shows the comparison between the results from the simulation and the actual field data. From the simulation, it is observed the results obtained from the simulation (after tuning) are well within the error margin (i.e., less than 10\%) of the OLGA simulator. Figure 9 to Figure 10illustrate the comparison of temperature trends for the history matching simulations and field data. The temperature variation is approximately $0.2 \%$ to $3.5 \%$ difference. Meanwhile, the matching results of the pressure is more difficult to obtain than temperature, but it is still in the acceptable range $6 \%$ to $8.4 \%$ difference (as shown in Figure 11 and Figure 12).

Table 4. Pressure \& Temperature for History Matching

\begin{tabular}{|c|c|c|c|c|c|c|}
\hline \multirow{2}{*}{ Platform/Location } & \multicolumn{3}{|c|}{ Average Pressure (psig) } & \multicolumn{2}{c|}{ Average Temperature ( ${ }^{\circ}$ C) } \\
\cline { 2 - 7 } & Simulation & $\begin{array}{c}\text { Field } \\
\text { Data }\end{array}$ & $\begin{array}{c}\text { Difference } \\
(\%)\end{array}$ & Simulation & Field Data & $\begin{array}{c}\text { Difference } \\
(\%)\end{array}$ \\
\hline STN-S & 349.9 & 329.3 & 6.3 & 109.7 & 110.8 & -0.9 \\
\hline WHP-B Inlet & $215-245$ & $61.4-81$ & 6 & 110 & 109.8 & 0.2 \\
\hline Separator (at CPP) & $140-180$ & $55-65$ & 8.4 & 75 & 72.5 & 3.5 \\
\hline
\end{tabular}

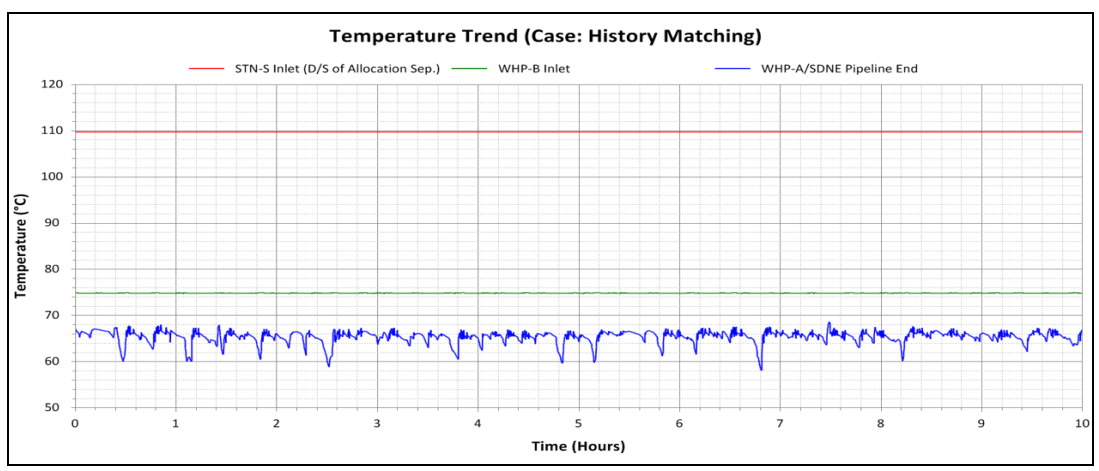

Figure 9. Temperature trend at STN-S / WHP-B / CPP (History Matching Simulation)

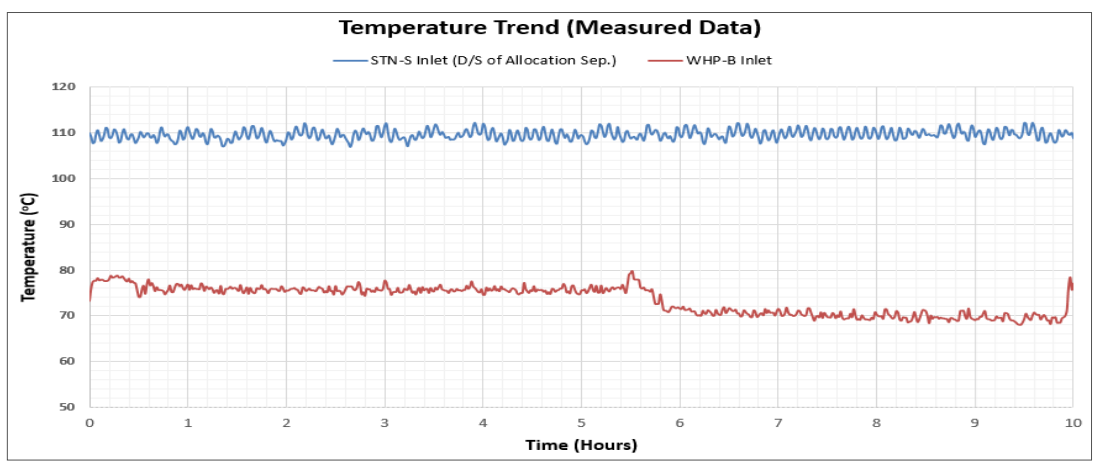

Figure 10. Temperature trend at STN-S / WHP-B / CPP (Field Data) 


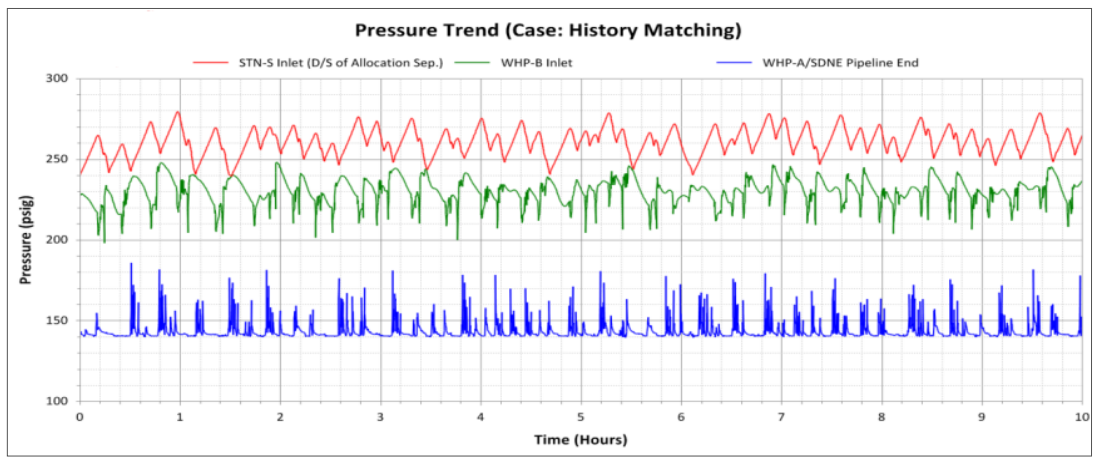

Figure 11. Pressure trend at STN-S / WHP-B / CPP (History Matching Simulation)

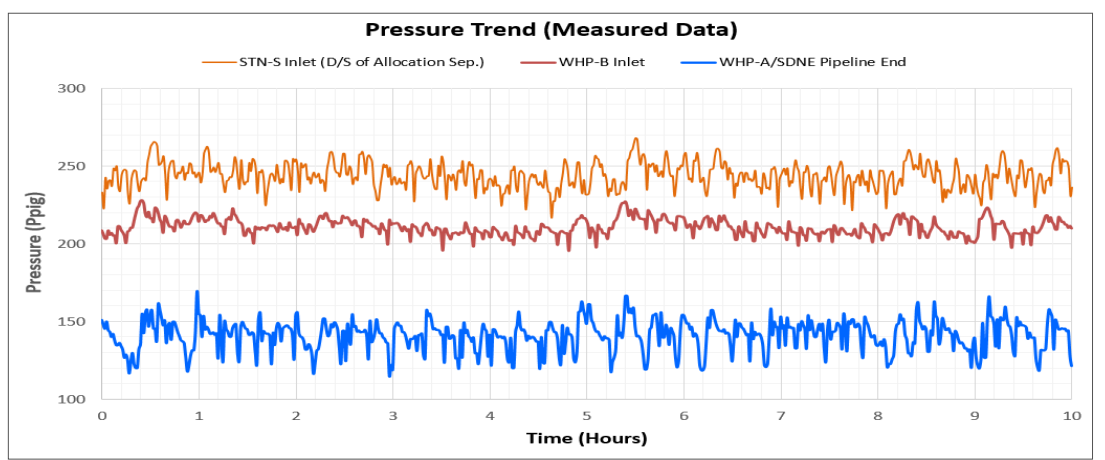

Figure 12. Pressure trend at STN-S / WHP-B / CPP (Field Data)

\section{CONCLUSION}

On the basis of the multiphase flow model theory, also,understanding of governing factor influencing slugging behavior in operation system, the stepsmodeling and calibrating thermo-hydraulic modelwere described and appliedfor Lion fields in this study.

The boundaries pressure, and delay constant of slugging process is used as the key factors which influence on the slug flow in the pipeline system and quality of model in sensitivity analysis. The results showed that the boundary pressure of STN-S (230 psig), WHP-B inlet $(230 \mathrm{psig})$, and the delay constant of slugging process (2000) are vital to obtaining a good match model. The average difference (i.e., less than 5\%) in temperature and (i.e., less than $10 \%)$ pressure are considered well within the error limit of the OLGA simulation. This mean that the thermal-hydraulic model developed for the subsea connection system of Lion fields can be used to assess the impact of slugging on surface facility production operations and evaluate the pipeline's thermal and hydraulic performance in the future. 


\section{Mô hình hóa dòng chảy nút lỏng trong đường ống vận chuyển dầu khí đa pha các mỏ sư tử}

- $\quad$ Đỗ Xuân Hòa ${ }^{1}$

- Mai Cao Lân ${ }^{2}$

${ }^{1}$ Công ty Liên doanh Điều hành Cửu Long

${ }^{2}$ Khoa Kỹ thuật Địa chất \& Dầu khí, Trường Đại học Bách khoa, ĐHQG-HCM

\section{TÓM TĂT}

Việc ứng dụng phuơng án vận chuyển dầu khí bằng hệ thống đường ống kết nối giũa các mỏ nhỏ/mỏ cận biên có ý nghĩa quan trọng trong việc nâng cao hiệu quả phát triển mỏ. Tuy nhiên, khi nhiều hệ thống đường ống vận chuyển dầu khí tù̀ các mỏ khác nhau được thu gom chung về một hệ thống xủ lý trung tâm (CPP) hoạc tàu công nghệ xử lý và chứa (FPSO), úng xủ dầu khí trong dòng chảy đa pha diễn biến khá phức tạp và thường xuyên gây ra sụ bất ổn định cho dòng chảy trong đưòng ống hay còn gọi là hiện tuợng "slugging", tác động xấu đến hoạt động của các thiết bị xủ lý hạ nguồn. Vì vậy, việc khảo sát chế độ dòng chảy nút nhằm kiểm soát và cải thiện tính ổn định của dòng chảy trong hệ thống đường ống vận chuyển dầu khí là rất cần thiết. Trong bài báo này, các quy trình cho việc xây dưng và hiệu chỉnh mô hình dòng chảy đa pha sẽ được trình bày và úng dung cu thể cho hệ thống đường ống vận chuyển dầu khí nội mỏ Su Tử, bồn trũng Củu Long, Việt Nam. Phuong pháp phân tích ảnh huởng cũng được thực hiện nhằm khảo sát các yếu tố ảnh hưởng đến dòng chảy nút trong hệ thống đường ống. Các kết quả của mô hình sẽ là công cu hũu dụng trong việc theo dôi và kiểm soát ảnh huởng của hiện tuợng "slugging" đến hoạt động của bình tách hạ nguồn.

Tù khóa: Đảm bảo dòng chảy, dòng chảy nút lỏng, dòng chảy đa pha

\section{REFERENCES}

[1]. Y. Tang, T. Danielson, "Pipelines Slugging and Mitigation: Case Study for Stability and Production Optimization," SPE 102352, 2006.

[2]. Kjell H.Bendiksen, Dag Maines, Randl Moe, and Sven Nuland, "The Dynamic Two-Fluid Model OLGA: Theory and Application," SPE, 1991.

[3]. N.E. Burke, S.F. Kashou, and P.C. Hawker,
"History Matching of a North Sea Flowline Startup," JPT, 1993.

[4]. Ivor R. Ellul, Geir Saether, L.P, Mack E. Shippen, "The Modeling of Multiphase Systems under Steady-State and Transient Conditions - A Tutorial," PSIG, 2004.

[5]. S.C. Omowunmi, M. Abdulssalam, R. Janssen, P. Otigbah, "Methodology for Characterising Slugs and Operational 
Mitigation Strategy Using OLGA Slug Tracking Module - Egina Deepwater Project," OMC, 2013.

[6]. Shea, R., Eidsmoen, H., Nordsveen, M., Rasmussen J., Xu, Z., Nossen, J., "Slug Frequency Prediction Method Comparison," 4th North American Conference on Multiphase Technology, 2004.

[7]. O. Bratland, Pipe Flow 2 , Multiphase Flow
Assurance, 2009.

[8]. J.Takei, M. X. Xainal, and R. Ramli, Petronas Cargali Sdn. Bhd.; B. Matzain and F. Myrland, SPT Group Pty Ltd.; A. M. Shariff, Universiti Teknologi Petronas, "Flow Instability in Deepwater Flowlines and Risers-A Case Study of Subsea Oil Production from Chinguetti Field, Mauritania," SPE133138, 2010. 